\title{
Effects of Moderate Electric Fields on the Post-harvest Preservation of Chestnuts
}

\author{
Enrique Pino-Hernández ${ }^{1}$ (D) Ricardo N. Pereira $^{1}$ (D) - Lina F. Ballesteros ${ }^{1}$ (D) - António A. Vicente ${ }^{1}$ (D) \\ Luís Abrunhosa ${ }^{1}$ (1) J José A. Teixeira ${ }^{1}$ (i)
}

Received: 16 December 2020 / Accepted: 17 February 2021 / Published online: 11 March 2021

(C) The Author(s), under exclusive licence to Springer Science+Business Media, LLC, part of Springer Nature 2021

\begin{abstract}
Ohmic heating $(\mathrm{OH})$ was evaluated as a post-harvest technology to improve chestnuts' shelf-life (Castanea sativa Mill.) by controlling molds and insect larvae proliferation. Chestnuts were processed by $\mathrm{OH}$ at 35,45 , and $55^{\circ} \mathrm{C}$ and compared with untreated fruits and the conventional hydrothermal technology $\left(\mathrm{HT}-50^{\circ} \mathrm{C}\right.$ for $45 \mathrm{~min}$ ), which is the process currently used by the chestnut industry. Shelf-life studies were carried out at different atmospheric conditions for 60 days: (i) $25^{\circ} \mathrm{C}$ and $40 \%$ relative humidity (RH); (ii) $5{ }^{\circ} \mathrm{C}$ and $70 \% \mathrm{RH}$. The results show that the $\mathrm{OH}$ conducted at $55^{\circ} \mathrm{C}\left(\mathrm{OH}-55^{\circ} \mathrm{C}\right)$, combined with storage at 5 ${ }^{\circ} \mathrm{C}$, was more effective in controlling molds and larvae growth than the other treatments. Moreover, under these conditions, chestnuts' shelf-life could be extended for 60 days without substantial changes in the fruits' color and texture. After the $\mathrm{OH}-55^{\circ} \mathrm{C}$ treatment, lower losses of some nutrients and vitamin $\mathrm{C}$ were registered compared to HT. This study demonstrates for the first time that $\mathrm{OH}$ has the potential to be used by the chestnut industry for the post-harvest disinfestation of this fruit.
\end{abstract}

Keywords Ohmic heating $\cdot$ Martaínha chestnut $\cdot$ Shelf-life $\cdot$ Fungi $\cdot$ Weight loss

\section{Introduction}

Chestnuts are the fruit of the genus Castanea (Zhu, 2017). Data collected in 2018 show that the worldwide production of chestnuts was around 2.35 million tons, with China being the primary contributor with a share of $83 \%$ (FAOSTAT, 2020). In the European Union, chestnut production represents only $6 \%$ of the global market. Italy, Greece, Portugal, Spain, and France are the primary producers in Europe. According to FAOSTAT (2020), Portuguese chestnut production was 34,165 tons in 2018.

The consumption of chestnut fruits has increased in recent years because of their interesting nutritional properties, unique flavor, and potential as a functional food (Bounous et al., 2002; FAOSTAT, 2020; Wang et al., 2020; Zhu, 2017). The chestnut kernel is low in protein and fat, contains several essential fatty acids, and is rich in starch-its primary component (Hou et al., 2018; Zhang et al., 2018; Zhu, 2016). Chestnuts are also an excellent source of vitamin $\mathrm{C}$ and are

Luís Abrunhosa

luisjap@deb.uminho.pt

1 CEB - Centre of Biological Engineering, University of Minho, Campus de Gualtar, 4710-057 Braga, Portugal gluten-free (Ribeiro et al., 2007; Wang et al., 2020; Zhu, 2017). Nevertheless, unlike other edible nuts, chestnuts are fruits with a relatively high moisture content and metabolic activity (Blaiotta et al., 2014). Therefore, chestnuts have a limited shelf-life and are prone to post-harvest decay, suffering weight loss due to dehydration, undesired changes in color and texture, and growth of insect larvae and fungi, if not adequately processed or stored (Vettraino et al., 2020; Zhao et al., 2018; Zhu, 2016).

Fumigation with methyl bromide ( $\mathrm{MeBr}$ ) has been used in the past to extend chestnuts' shelf-life (UNEP, 2014). Because of its ozone-depleting properties, $\mathrm{MeBr}$ production and use were banned worldwide after the Montreal Protocol (UNEP, 2014). Since then, other preservation methods such as the immersion in cold water (water curing at $15-20{ }^{\circ} \mathrm{C}$ for $3-9$ days) and the immersion in hot water (hydrothermal process at $47-50{ }^{\circ} \mathrm{C}$ for $30-45 \mathrm{~min}$ ) have been used by the chestnut industry (Bounous et al., 2002). Nonetheless, the long processing times of these methods contribute to raising the moisture content of chestnuts (Neri et al., 2010; Silva et al., 2011), thus increasing the risk of deterioration during the storage period due to fungal growth (Vettraino et al., 2020).

The existing drawbacks in current chestnuts' post-harvest treatments together with the increasing demand for high- 
quality food, the industrial concerns about food preservation, safety and shelf-stable life of the products, and the existing environmental requirements have triggered the need for new post-harvest processing technologies for chestnuts. Several alternative treatments have been studied with more or less success and reviewed by Zhu (2016). Some of the reported strategies are described as follows: (i) hot air $\left(55-62{ }^{\circ} \mathrm{C}\right)$ assisted by radiofrequency $(6 \mathrm{~kW}, 27.12 \mathrm{MHz})$ followed by storage at 4 $35^{\circ} \mathrm{C}$ and $95 \%$ relative humidity (RH) (Hou et al., 2014, 2015, 2018); (ii) microwaves at $420-900 \mathrm{~W}$ during $1.5-15 \mathrm{~min}$ (Wani et al., 2017; Zhang et al., 2018); (iii) natural air drying at 15-25 ${ }^{\circ} \mathrm{C}$ and $\mathrm{RH}$ of $20-40 \%$ during $\geq 4$ days (Wang et al., 2020; Zhang et al., 2018; Zhao et al., 2018); (iv) electron beam and gamma irradiation at $0-10 \mathrm{kGy}$ followed of storage at $4{ }^{\circ} \mathrm{C}$ and 90-95\% RH (Barreira et al., 2012; Carocho et al., 2012, 2014; Fernandes et al., 2011a, b); (v) controlled atmosphere (150$300 \mathrm{ppb}$ of $\mathrm{O}_{3}$ or $15.20 \mathrm{kPa} \mathrm{CO}_{2}$ and $3.04 \mathrm{kPa} \mathrm{O}_{2}$ ) and storage temperature at $-1{ }^{\circ} \mathrm{C}$ and $95 \% \mathrm{RH}$ (Vettraino et al., 2019, 2020); and (vi) packaging in a $\mathrm{CO}_{2}$-enriched and $\mathrm{O}_{2}$ impoverished atmosphere $\left(10-80 \% \mathrm{CO}_{2}, 0.3-10.5 \% \mathrm{O}_{2}\right.$ and $\mathrm{N}_{2}$ as filler) followed by storage at 0 and $8{ }^{\circ} \mathrm{C}$ (Fernandes et al., 2020a, b; Panagou et al., 2006; Peano et al., 2014). However, many of these studies have not evaluated the treatment efficacy in controlling the fungal load.

During the last decade, ohmic heating $(\mathrm{OH})$ has emerged as a high-potential technology for food processing. $\mathrm{OH}$ is an environment-friendly technology that relies on the application of external moderate electric fields to create fast and uniform heating (Kaur \& Singh, 2016; Pereira \& Vicente, 2010). The process involves the application of a voltage on two electrodes located at the extremities of a container. The alternating current is forced to pass through the food material existing in the container, resulting in internal heat generation due to food electrical resistance - Joule effect (Pereira \& Vicente, 2010). $\mathrm{OH}$ has gained considerable interest because it can be used in a wide diversity of food processes such as blanching, evaporation, dehydration, thawing, extraction, peeling, fermentation, sterilization, and pasteurization (Kaur \& Singh, 2016; Pereira \& Vicente, 2010). OH has a rapid and uniform heating capacity, and the combined electrical and thermal effects can enhance the inactivation of microbes and enzymes with minimal thermal damage (Kaur \& Singh, 2016; Machado et al., 2010). Thus, foods with low nutritional losses and highly stable shelf-life are obtained (Kaur \& Singh, 2016).

The advantages of $\mathrm{OH}$ lie fundamentally on (i) its ability to quickly reach higher pasteurization temperatures; (ii) its low environmental impact due to its low energy consumption profile, which also helps to reduce processing costs; (iii) its short heating times, which allows small food cooking values $(C$ value) and low processing-dependent changes in quality (Jaeger et al., 2016); and (iv) its capacity to better preserve the nutritional, functional, structural, and sensory properties of food products than conventional thermal technologies.
However, the $\mathrm{OH}$ method is not devoid of disadvantages since the food's electrical conductivity is a critical property that influences the heating process uniformity. Therefore, food products with multi-phase components of different electrical conductivity may heat at different rates giving rise to nonuniform heating of the product and possible underprocessing or overprocessing (Pereira \& Vicente, 2010). On the other hand, the high investment costs and lack of regulatory framework have delayed the widespread use of this technology at an industrial scale (Pereira \& Vicente, 2010). Nonetheless, OH equipment suitable for operating in the industry's production lines is currently commercially available.

Considering the $\mathrm{OH}$ advantages and the demand for processing technologies that can maintain chestnuts' quality as similar to fresh as possible, this study aimed at evaluating the use of $\mathrm{OH}$ technology for the post-harvest treatment of chestnuts. The impact of $\mathrm{OH}$ on the chestnuts' shelf-life and physicochemical and nutritional properties was evaluated and compared with untreated fruits and chestnuts treated by the conventional hydrothermal treatment (HT), currently used in the chestnut industry.

\section{Material and Methods}

\section{Chestnuts Sampling}

Chestnuts (Castanea sativa Miller) from the Portuguese variety Martaínha were obtained in a local wholesaler unit (Frusantos, SA) from Sernancelhe, PDO of Soutos da Lapa, north of Portugal, in October 2018. Chestnuts with no apparent defects were harvested manually, packed in net bags by the wholesaler, and transported fresh to the laboratory.

\section{Post-harvest Processing of Chestnuts}

The fresh chestnuts, with an approximate average weight of $11.2 \mathrm{~g}$, were submerged in water, and the floating fruits were then discarded since it meant they were rotten, dehydrated, or immature, and thus unsuitable for use in this study. Subsequently, chestnuts were dried for 5 min with pressurized air at room temperature and divided into lots to be processed differently. One lot was used without any treatment and is described as "untreated" control. A second lot was then submitted to HT, which implied dipping the chestnuts in a $200 \mathrm{ppm}$ sodium hypochlorite solution at a temperature of $50{ }^{\circ} \mathrm{C}$ for $45 \mathrm{~min}$ with magnetic agitation. The fruits were then immersed in cold water for $15 \mathrm{~min}$ and dried for 5 min with pressurized air at room temperature, which allowed to remove excess water from the chestnut's shell. Finally, a third lot of chestnuts was submitted to $\mathrm{OH}$ at different temperatures $\left(35,45\right.$, and $\left.55^{\circ} \mathrm{C}\right)$. The treatments were conducted in an ohmic reactor $(8 \mathrm{~cm}$ diameter and 
$25 \mathrm{~cm}$ height) containing $500 \mathrm{~mL}$ of $0.02 \mathrm{M} \mathrm{NaCl}$ and $200 \mathrm{ppm}$ of sodium hypochlorite under constant magnetic stirring (Fig. 1). The electrical conductivity of chestnuts and $\mathrm{NaCl}$ solution was calculated according to Tulsiyan et al. (2008), being approximately $2.02 \mathrm{mS} / \mathrm{cm}$ and $2.23 \mathrm{mS} / \mathrm{cm}$ at $25{ }^{\circ} \mathrm{C}$, respectively. $\mathrm{OH}$ was performed using a digital function generator $(1 \mathrm{~Hz}-25 \mathrm{MHz}$ and $1-10 \mathrm{~V}$; Agilent 33220A, Penang, Malaysia) to produce a sinusoidal electric wave of small peak voltage. The generated electric wave was then amplified (Peavey CS3000, Meridian, MS, USA) and delivered to the ohmic reactor. A portable oscilloscope (ScopeMeter 125/S, Fluke, WA, USA) was used to measure the electrical frequency, voltage, and current intensity during the $\mathrm{OH}$ treatments. The applied moderate electric field was $9 \mathrm{~V} / \mathrm{cm}$ with an electrical frequency of $25 \mathrm{kHz}$. Two temperature probes (Type-K thermocouple $\pm 1{ }^{\circ} \mathrm{C}$, Omega Engineering, Inc., Stamford, CT, USA) were used during the process. One was placed in the geometric center of one chestnut, while the other was put in the surrounding water (Fig. 1). Both probes were connected to a data logger (USB9161, National Instruments Corporation, Austin, TX, USA) to record the treatments' temperature using Lab View 7 Express software (National Instruments, NI Data logger).

Fig. 1 Schematic view of the ohmic heating reactor
The $\mathrm{OH}$ process was stopped as soon as the target temperature was reached in the fruits' geometric center. At that point, the water temperature exceeded the temperature registered in the chestnut center in $\pm 10.5^{\circ} \mathrm{C}$. On average, the times taken to achieve target temperatures of $35^{\circ} \mathrm{C}, 45^{\circ} \mathrm{C}$, and $55^{\circ} \mathrm{C}$ were $2.00,2.83$, and $3.33 \mathrm{~min}$, respectively. After the $\mathrm{OH}$ treatment, the chestnuts were cooled with cold water and dried for $5 \mathrm{~min}$ with pressurized air at room temperature to remove excess water. For both treatments, batches of 5 chestnuts were processed until $10 \mathrm{~kg}$ of treated fruits were obtained for each condition.

\section{Analysis Performed Before and Immediately After Each Treatment}

\section{Weight Gain Determination}

Weight gain of treated chestnuts was evaluated by weighing the chestnut fruits before and immediately after the treatments. Weight gain was expressed as a percentage of the initial chestnuts' weight and represents the percentage of water incorporated into the chestnuts during each treatment.

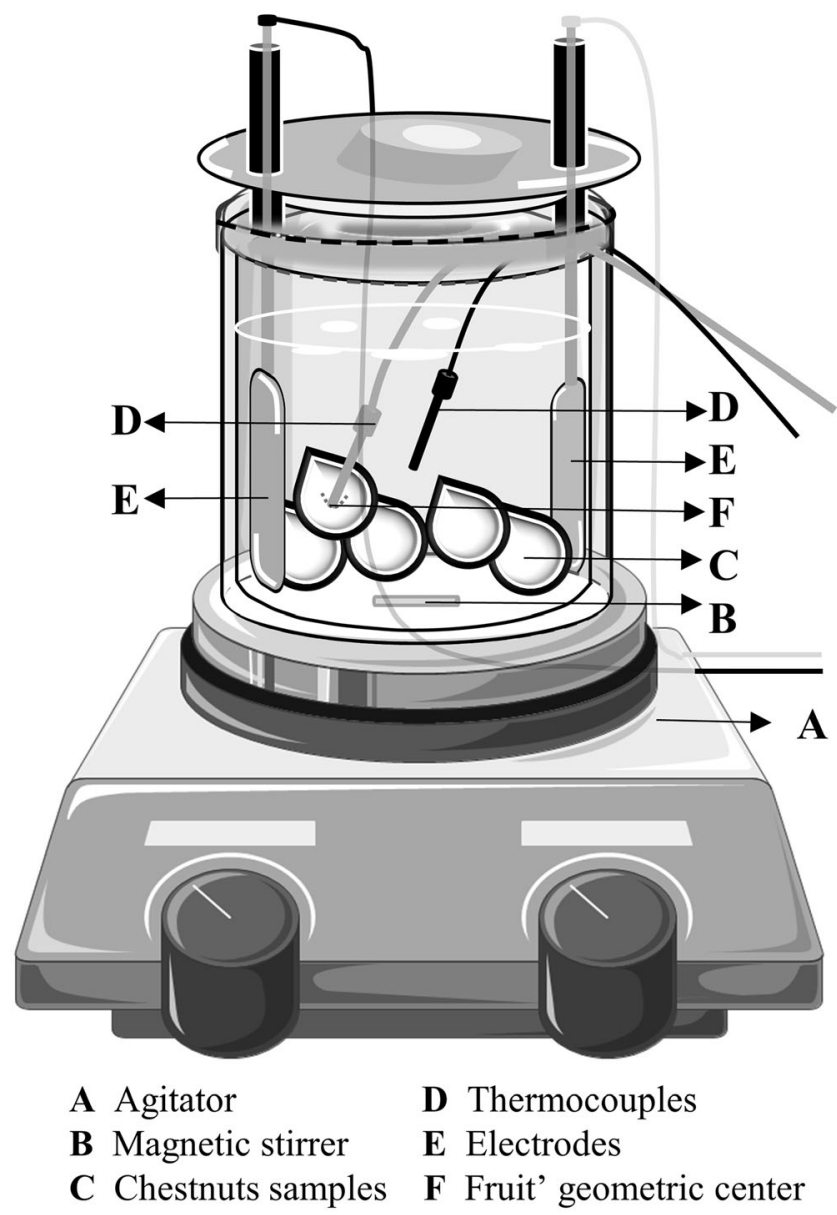


Proximate, Starch, Sugars, and Ascorbic Acid Analysis

\section{Sample Preparation}

Before and immediately after each treatment, $1 \mathrm{~kg}$ of chestnuts was taken randomly from each lot. Then, the chestnuts were peeled, placed on trays, frozen at $-80^{\circ} \mathrm{C}$ (Thermo Scientific, Forma 8600, USA), and lyophilized for $30 \mathrm{~h}$ (Christ alpha 1-4 LDplus, Germany). The lyophilized chestnuts were pulverized using a grinder (Taurus, Aromatic II, Portugal) and were sifted to obtain 40 mesh powder. Finally, the chestnut flours were vacuum packaged and stored at room temperature for subsequent analysis. All the analyses were carried out in triplicate.

\section{Proximate Composition}

The samples were analyzed for proximate composition (moisture, fat, ash, and protein) using the procedures previously described by Gonçalves et al. (2010). Moisture content was evaluated by drying $2.5 \mathrm{~g}$ of chestnut kernels in an oven at 105 ${ }^{\circ} \mathrm{C}$ (Thermo Electron, T6 Heraeus) until constant weight. The total content of lipids was obtained by Soxhlet extraction (Soxtec 8000, Foss) using petroleum ether (ChemLab, CL00.1608). Ash content was determined after incineration of $1.5 \mathrm{~g}$ of dried samples in a muffle furnace at $550{ }^{\circ} \mathrm{C}$ (Nabertherm, D2804). Total protein content was determined by the Kjeldahl method (Kjeltec 8400, Foss) using the conversion factor of 5.30, which is specific for chestnut fruit (Pereira-Lorenzo et al., 2006).

\section{Total and Resistant Starch Determination}

Total starch was determined using the assay kit amyloglucosidase $/ \alpha$-amylase method (AMG/AA) from Megazyme (Ireland). The analysis was performed according to the instructions supplied by the manufacturer. The calculations were done using the Mega-Calc ${ }^{\mathrm{TM}}$ Excel ${ }^{\circledR}$ based calculator (AMG/AA), also provided by Megazyme. Resistant starch, defined as the starch which is not digested within $4 \mathrm{~h}$, was determined using the assay kit digestible starch/resistant starch (K-DSTRS) from Megazyme (Ireland). The analysis was performed according to the manufacturers' instructions and the calculations using the Megazyme Mega-Calc ${ }^{\text {TM }}$ Excel ${ }^{\circledR}$ based calculator (K-DSTRS). Both types of starch content were expressed as a mass percentage of lyophilized material.

\section{Soluble Sugars Determination}

The sample preparation for soluble sugars determination was performed according to the method described by Hou et al. (2014) with some modifications. Briefly, a sample of lyophilized chestnut powder $(1.0 \mathrm{~g})$ was dissolved in $10 \mathrm{~mL}$ of $80 \%(\mathrm{v} / \mathrm{v})$ aqueous ethanol and heated at $80{ }^{\circ} \mathrm{C}$ in a waterbath with magnetic agitation for $30 \mathrm{~min}$. The resulting suspension was cooled, centrifuged at $2500 \mathrm{~g}, 4^{\circ} \mathrm{C}, 20 \mathrm{~min}$ (Heraeus, Multifuge X3R, Portugal), and the supernatant filtered through $0.22 \mu \mathrm{m}$ cellulose membrane and then refrigerated until analysis. After that, soluble sugar was performed through the anthrone-sulfuric acid assay, as reported by Leyva et al. (2008). The absorbance was determined at $620 \mathrm{~nm}$ in a spectrophotometer microplate reader (Synergy HT, Biotek, USA) using distilled water as blank. A six-point calibration curve was prepared using a standard glucose solution $(0.020$ to 0.40 $\mathrm{g} / \mathrm{L}$ ), and the content of total soluble sugars was expressed as $\mathrm{g}$ glucose/100 g dry weight.

\section{Ascorbic Acid Determination}

The analysis of vitamin $\mathrm{C}$ was performed using the ascorbic acid assay kit (K-ASCO) from Megazyme (Ireland). The calculation of L-ascorbic acid content was performed using the Megazyme Mega-Calc ${ }^{\mathrm{TM}}$ Excel ${ }^{\circledR}$ based calculator (KASCO). The L-ascorbic acid content was expressed as $\mathrm{mg} / \mathrm{kg}$ of lyophilized material.

\section{Nutrients and Vitamin C Retention}

The nutrient and vitamin $\mathrm{C}$ retention based on the fruit's edible part after each treatment were calculated using Eq. (1) (Bogna \& Piekarski, 2000).

Retention $\%=\frac{n c / 100 g t s}{n c / 100 g f s} \times \frac{\operatorname{swap}(g)}{\operatorname{swbp}(g)} \times 100$

where $n c$ is the nutrient content; $t s$ is the treated sample; $f s$ is the untreated sample; swap is the sample weight after processing; $s w b p$ is the sample weight before processing.

\section{Cooking Value}

The degree of cooking, expressed in terms of the cooking value $(C)$ induced by each treatment, was calculated according to Ling et al. (2015) using Eq. (2).

$C_{\text {Tref }}^{Z}=\int_{0}^{t} 10^{(T-T r e f) / z_{Q}} d t$

where $d t$ is the differential time used in the processing of chestnuts, Tref the cooking reference temperature $\left(100^{\circ} \mathrm{C}\right)$, $Z_{Q}$ the reference cooking temperature increase $\left(33^{\circ} \mathrm{C}\right)$ that induces a 10-fold increase of the overall rate of the involved chemical reactions. The processing time and temperature were measured in the chestnut center by the thermocouple, as described before. 


\section{Shelf-Life Studies}

Before and immediately after the chestnuts' post-harvest processing, the obtained lots (identified as untreated, HT, $\mathrm{OH}-35{ }^{\circ} \mathrm{C}, \mathrm{OH}-45{ }^{\circ} \mathrm{C}$, and $\mathrm{OH}-55^{\circ} \mathrm{C}$ ) were divided into two and stored separately under different atmospheric conditions: (i) at $5{ }^{\circ} \mathrm{C}$ and $70 \% \mathrm{RH}$ (to simulate the wholesaler refrigerated storage chambers) and (ii) at 25 ${ }^{\circ} \mathrm{C}$ and $40 \% \mathrm{RH}$ (to simulate the wholesaler storage at room temperature). Chestnuts were placed in open plastic boxes and stored for 60 days in those conditions using incubators (Binder, KBF 115, Germany) with automatic temperature and $\mathrm{RH}$ control. The temperature and $\mathrm{RH}$ of the different storage conditions were monitored along with the shelf-life using an iButton data logger. The microbiological (bacteria and molds) and weight loss analyses were done before and immediately after the chestnuts treatments ( 0 days of storage) and within 8-day intervals of storage. The visual quality of chestnuts was assessed at 0,30 , and 60 days of storage, while their color and texture were measured on days 0 and 60 . The analyses were performed as explained below.

\section{Microbiological Analyses}

The microbial load of five chestnuts was determined as follows: in a laminar flow chamber (Scanlaf Mars EB7, Denmark), using sterilized instruments, the whole fruits were cut into small pieces and added to $350 \mathrm{~mL}$ of sterile buffered peptone water (1.07228, Merck). The mixture was shaken for about $30 \mathrm{~min}$ and serially diluted up to $10^{5}$ using the same peptone solution. Adequate dilutions were plated on Plate Count Agar (PCA, PanReac AppliChem) and Rose-Bengal (RBC, PanReac AppliChem) agar plates in triplicate and incubated for 28 days in the dark at $30{ }^{\circ} \mathrm{C}$ and $25{ }^{\circ} \mathrm{C}$, respectively (Blaiotta et al., 2014). The colonies counted were expressed as log CFU per gram of chestnut.

\section{Weight Loss Determination}

Weight loss was monitored along the storage period using a technical balance (Kern, ABS 320-4N, Germany) and expressed as a percentage variation relative to the fruits' weight at the beginning of the storage. The weight loss $(W L)$ was determined according to Eq. 3:

$W L=\left(1-W_{t} / W_{0}\right)$

where $W_{0}$ is the initial sample weight, and $W_{t}$ is the sample weight at time $t$.

\section{Color Determination}

Color parameters were measured using a colorimeter (Chroma meter CR-400, Konica Minolta, Japan) with a D65 light source. The measurements were made on the external (shell) and internal (kernel) parts of the fruits at three different points. Color images of six chestnuts per treatment were captured. The results were expressed according to CIE $L^{*} a^{*} b^{*}$ color space definition. In the CIE $L^{*} a^{*} b^{*}$ color space, $L^{*}$ is brightness (varying from $0=$ black to $100=$ white), $a^{*}$ varies from green $\left(-a^{*}\right)$ to red $\left(+a^{*}\right)$, and $b^{*}$ varies from blue $\left(-b^{*}\right)$ to yellow $\left(+b^{*}\right)$. Also, the color difference $\left(\Delta E^{*}\right)$ CIE76 was calculated according to Eq. 4 .

$\Delta E^{*}=\sqrt{\left(\Delta L^{*}\right)^{2}+\left(\Delta a^{*}\right)^{2}+\left(\Delta b^{*}\right)^{2}}$

where $\Delta L^{*}, \Delta a^{*}$, and $\Delta b^{*}$ are the differences between the color parameter of the samples processed over the storage and the color parameter of the control sample at 0 days of storage.

\section{Texture Determination}

Measurements of chestnut texture were done at room temperature using a Texture Analyzer (TA-XT. PLUS/50, Stable Micro System Ltd., UK) and the Exponent software (version 6.0.7.0, Stable Micro Systems Ltd., UK) to record the forcetime graphs.

A penetration force test to determine the puncture characteristic on the whole chestnut (kernel with shell) was performed using a 2-mm diameter probe and a load cell of 20 $\mathrm{kg}$. The puncture force was measured in $N$ from the penetration curve. The testing velocity was $2.0 \mathrm{~mm} / \mathrm{s}$. Tests were conducted on ten chestnuts per treatment.

A compression test was also performed on the chestnut kernel. The texture analyzer was equipped with a probe of $75 \mathrm{~mm}$ and a load cell of $50 \mathrm{~kg}$; the height was set to 20 $\mathrm{mm}$, the reserved height to $3 \mathrm{~mm}$, the test speed to $1 \mathrm{~mm} / \mathrm{s}$, the hold time to $2 \mathrm{~s}$, the retraction speed to $5 \mathrm{~mm} / \mathrm{s}$, the trigger force to $20 \mathrm{~g}$, and the compression percentage to $80 \%$. The maximum compression force (height of the first peak), defined as the firmness parameter, was recorded, and the measures were reported in $N$.

\section{Visual Quality Evaluation}

During the storage period, the chestnuts were visually inspected for insect larvae and mold growth, dehydration, and sprouting. At each sampling time, fourteen fruits were cut in half and examined, both externally and internally. The degree of these occurrences was determined using a qualitative scale (Fig. 2). This scale covered the absence (-), some occurrence $( \pm)$, or the heavy occurrence $(+)$ of each referred 
Fig. 2 Qualitative parameters of visual inspection of chestnuts' shell and kernel. *Chestnuts that went to the bottom after being submerged in water were not dried; **chestnuts that floated after being submerged in water were dried; na - not applicable

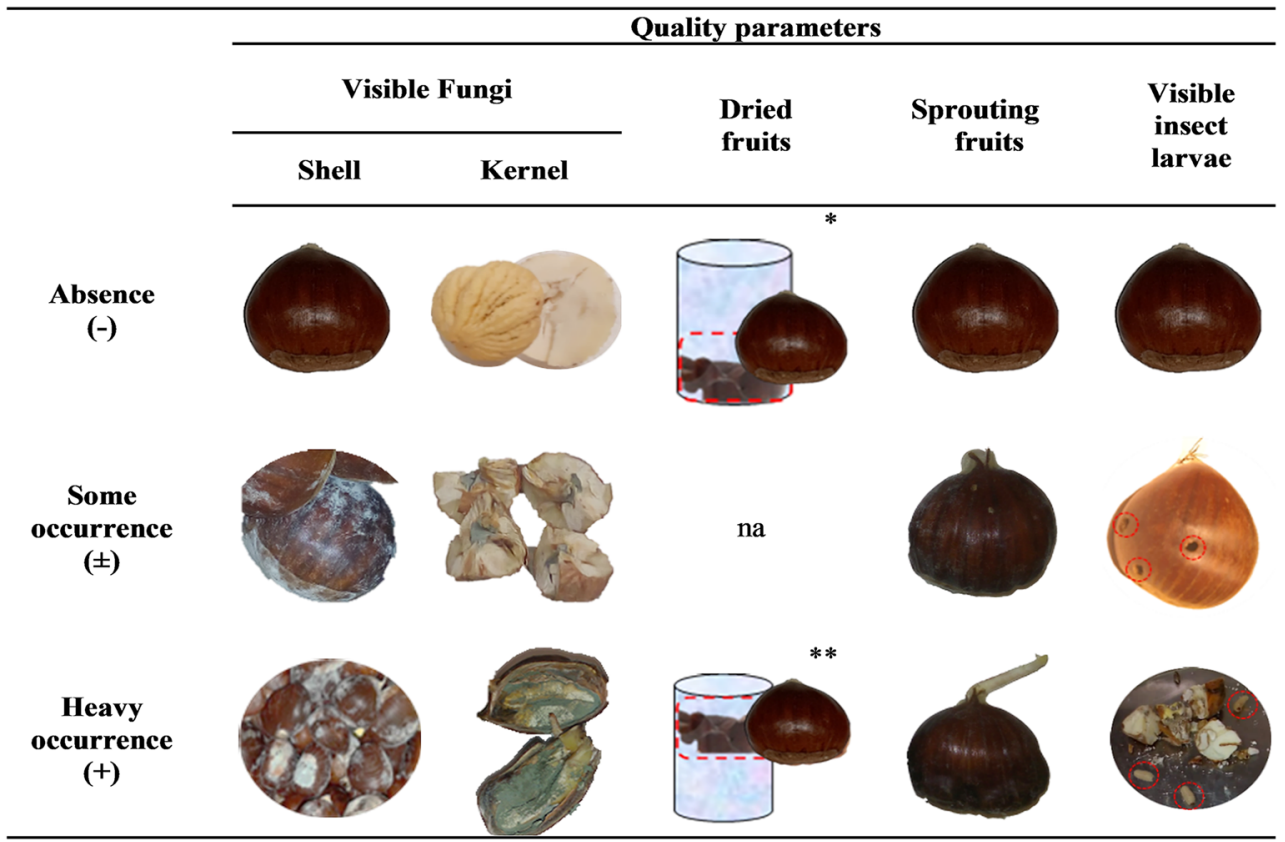

parameter (presence of insect larvae, visible molds, fruits dehydration, and sprouting). The dehydration was assessed by immersing chestnuts in water, as already explained previously.

\section{Statistical Analysis}

The results were compared by analysis of variance (ANOVA) and Tukey's test at a significance level of 5\% using the GraphPad Prism v6. Ink software. The data reported are expressed as the average of triplicate observations \pm standard deviation.

\section{Results and Discussion}

\section{Effects of Treatments on Chestnuts' Chemical Properties and Cooking Value}

The proximate chemical composition, resistant starch, and vitamin $\mathrm{C}$ contents of untreated and treated chestnuts' kernels are shown in Table 1 . Moisture $(46.1 \%)$ and carbohydrates $(88.2 \mathrm{~g} / 100 \mathrm{~g})$ are the most abundant components of the edible part of Martaínha chestnuts. The crude protein, fat, and ash represent less than $11.8 \mathrm{~g} / 100 \mathrm{~g}$ of the fruit. Among carbohydrates, starch accounted for $71.0 \mathrm{~g} / 100 \mathrm{~g}$ and soluble sugars
Table 1 Proximate composition ( $\mathrm{g} / 100 \mathrm{~g}$ in dry weight) of chestnuts' kernel before and immediately after the treatments

\begin{tabular}{|c|c|c|c|c|c|}
\hline \multirow[t]{2}{*}{ Parameters } & \multicolumn{5}{|l|}{ Treatments } \\
\hline & Untreated & Hydrothermal & $\mathrm{OH}-35^{\circ} \mathrm{C}$ & $\mathrm{OH}-45^{\circ} \mathrm{C}$ & $\mathrm{OH}-55^{\circ} \mathrm{C}$ \\
\hline Moisture $^{*}$ & $46.1 \pm 0.7^{\mathrm{a}}$ & $51.6 \pm 0.4^{\mathrm{b}}$ & $46.2 \pm 0.9^{\mathrm{a}}$ & $47.0 \pm 0.3^{\mathrm{a}}$ & $49.8 \pm 0.2^{\mathrm{c}}$ \\
\hline \multicolumn{6}{|l|}{ Carbohydrates } \\
\hline Starch & $71.0 \pm 0.5^{\mathrm{a}}$ & $67.0 \pm 0.2^{\mathrm{b}}$ & $68.3 \pm 0.7^{\mathrm{c}}$ & $68.1 \pm 0.2^{\mathrm{cd}}$ & $67.3 \pm 0.1^{\mathrm{bd}}$ \\
\hline Soluble sugars & $17.2 \pm 0.1^{\mathrm{a}}$ & $22.3 \pm 0.3^{\mathrm{b}}$ & $20.2 \pm 0.2^{\mathrm{c}}$ & $20.1 \pm 0.40^{\mathrm{c}}$ & $21.4 \pm 0.1^{\mathrm{d}}$ \\
\hline Resistant starch & $24.6 \pm 0.3^{\mathrm{a}}$ & $24.7 \pm 0.5^{\mathrm{a}}$ & $28.1 \pm 0.2^{\mathrm{b}}$ & $23.4 \pm 0.5^{\mathrm{a}}$ & $24.0 \pm 0.6^{\mathrm{a}}$ \\
\hline Crude protein & $5.5 \pm 0.1^{\mathrm{a}}$ & $4.7 \pm 0.1^{\mathrm{b}}$ & $5.1 \pm 0.0^{\mathrm{ab}}$ & $5.1 \pm 0.0^{\mathrm{ab}}$ & $5.0 \pm 0.1^{\mathrm{ab}}$ \\
\hline Crude fat & $4.6 \pm 0.4^{\mathrm{a}}$ & $4.0 \pm 0.2^{\mathrm{b}}$ & $4.6 \pm 0.1^{\mathrm{a}}$ & $4.8 \pm 0.2^{\mathrm{a}}$ & $4.6 \pm 0.1^{\mathrm{a}}$ \\
\hline Ash & $1.7 \pm 0.1^{\mathrm{a}}$ & $2.0 \pm 0.2^{\mathrm{a}}$ & $1.8 \pm 0.1^{\mathrm{a}}$ & $1.9 \pm 0.1^{\mathrm{a}}$ & $1.7 \pm 0.1^{\mathrm{a}}$ \\
\hline Vitamin $C^{* *}$ & $45.1 \pm 0.1^{\mathrm{a}}$ & $39.9 \pm 0.2^{\mathrm{b}}$ & $44.2 \pm 0.1^{\mathrm{ac}}$ & $43.6 \pm 0.3^{\mathrm{c}}$ & $41.5 \pm 0.1^{\mathrm{d}}$ \\
\hline
\end{tabular}

Values are expressed as means \pm standard deviation (SD)

${ }^{*}$ Value is presented as a percentage on a wet weight base

${ }^{* * *}$ Data is presented in $\mathrm{mg} / \mathrm{kg}$ on a dry weight base

Means with different superscript letters in a row are significantly different $(p<0.05)$. Untreated - not processed, Hydrothermal - conventional treatment, $\mathrm{OH}$ - ohmic heating 
for $17.2 \mathrm{~g} / 100 \mathrm{~g}$. Additionally, $24.6 \mathrm{~g} / 100 \mathrm{~g}$ of the edible part was resistant starch. This proximate composition agrees with data previously reported by Gonçalves et al. (2010) for Martaínha chestnuts, who found moisture contents of $50.0 \%$, and quantities of ash, protein, and fat of $1.7,4.5$, and $3.8 \mathrm{~g} / 100$ $\mathrm{g}$, respectively. The results obtained in this study also agree with data previously reported by Wang et al. (2020) and Barreira et al. (2012), who found values of moisture between 44.7 and $50.0 \%$ for Chinese and Turkish chestnuts, respectively. As already mentioned, the fruit's high moisture content is a determinant parameter for its post-harvest storage because it can potentiate molds' proliferation and decay. On the other hand, the carbohydrates content of Turkish and Portuguese chestnuts have been estimated in $91.0-94.0 \mathrm{~g} / 100 \mathrm{~g}$ by Barreira et al. (2012) and Cruz et al. (2013); and the total starch content in 71.1-93.2 g/100 g by Li et al. (2016), Cruz et al. (2013), and Neri et al. (2010). In what concerns the resistant starch, values of 17.2-30.6 g/100 g were reported by Cruz et al. (2013) and Correia et al. (2012). Regarding the other components, values of crude protein (4.8-6.2 g/ $100 \mathrm{~g})$, fat $(2.5-5.9 \mathrm{~g} / 100 \mathrm{~g})$, and ash (1.9-2.3 g/100 g) have been previously reported (Barreira et al., 2012; Gonçalves et al., 2010; Hou et al., 2014; Neri et al., 2010). As for vitamin $\mathrm{C}$, the contents found in this study (i.e., $39.9-45.1 \mathrm{mg} / \mathrm{kg}$ ) are similar to values $(12.8-47.5 \mathrm{mg} / \mathrm{kg})$ obtained previously by Ribeiro et al. (2007).

In regard to changes that the processing methods may have induced, significant differences $(p<0.05)$ were observed in moisture, crude protein, soluble sugars, and vitamin $\mathrm{C}$ after some treatments. In particular, it was found that chestnuts' moisture content increased significantly by $5.5 \%$ after the HT treatment. This increase can be attributed to the long immersion time in hot water ( $45 \mathrm{~min}$ ) that is necessary to treat the fruits. The $\mathrm{OH}$ treatments also influenced the final moisture percentages of the fruits but to a lesser extent; increases of 0.1 , 0.9 , and $3.7 \%$ for $\mathrm{OH}-35{ }^{\circ} \mathrm{C}, \mathrm{OH}-45^{\circ} \mathrm{C}$, and $\mathrm{OH}-55^{\circ} \mathrm{C}$ were respectively observed. The differences were only significant in $\mathrm{OH}-55{ }^{\circ} \mathrm{C}$ treatment. Additionally, regarding the HT samples, the increase of moisture content after the treatment was significantly higher $(p<0.05)$ than those registered after the $\mathrm{OH}$ treatments. The obtained moisture values agree with data of Gonçalves et al. (2010), Neri et al. (2010), Silva et al. (2011), and Hou et al. (2018), who reported moisture values between 45 and $58 \%$ for chestnuts that were treated with boiling water, cold water, and radiofrequency, respectively.

The total protein content of chestnuts decreased significantly $(p<0.05)$ after the HT treatment at $50{ }^{\circ} \mathrm{C}$ for $45 \mathrm{~min}$, suggesting some protein denaturation. The results agree with Gonçalves et al. (2010), who reported a 3.5\% decrease in chestnuts' protein content after being boiled for $20 \mathrm{~min}$. On the other hand, the $\mathrm{OH}$ treatments did not show a statistical difference $(p>0.05)$ in crude protein compared to untreated and HT samples. The crude fat content also showed a significant difference $(p<0.05)$ after the HT processing, decreasing $0.6 \%$ compared to untreated samples. The fat content of OH samples was also significantly different $(p<0.05)$ from the HT samples, but not from the untreated ones. This behavior differs from the decreasing trend observed by Hou et al. (2014) in Chinese chestnuts when radiofrequency treatments were applied at $55^{\circ} \mathrm{C}$ for $5 \mathrm{~min}$ with an electrical frequency of 27.12 MHz.

In what concerns carbohydrates, a significant decrease $(p<$ 0.05 ) of starch content and a proportional increase of soluble sugars was observed in the treated chestnuts compared with untreated ones. This change was more pronounced in the HTand $\mathrm{OH}-55{ }^{\circ} \mathrm{C}$-treated chestnuts. The observed differences after the treatments can be attributed to starch degradation due to the temperature and treatment time conditions (Kan et al., 2016). These results agree with Correia et al. (2009), who found that sugar content increased with the processing temperature $\left(40-60^{\circ} \mathrm{C}\right)$, being this behavior more evident for temperatures of $50-60{ }^{\circ} \mathrm{C}$.

In this study, the treated chestnuts had a starch content of 67.0-68.3 g/100 g, while untreated chestnuts had $71.0 \mathrm{~g} / 100$ g. On the other hand, the soluble sugars were $20.1-22.3 \mathrm{~g} / 100$ $\mathrm{g}$ in processed fruits, while the original value was $17.2 \mathrm{~g} / 100$ $\mathrm{g}$. The soluble sugar contents found in this study are similar to data (19-22 g/100 g) previously reported by Carocho et al. (2012) and Fernandes et al. (2011a) after using electron beam and gamma radiation as processing methods. On the other hand, the sugar contents obtained were higher than the 10.0 $\mathrm{g} / 100 \mathrm{~g}$ obtained by Hou et al. (2014) when using radiofrequency on Chinese chestnuts. It should also be highlighted that $23.4-24.7 \mathrm{~g} / 100 \mathrm{~g}$ of the chestnut's edible part is resistant starch. The registered values for treated and untreated samples were not statistically different $(p>0.05)$.

The vitamin $\mathrm{C}$ content was also affected by the temperature and processing time. The highest decrease of $5.2 \%(p<0.05)$ was observed in chestnuts treated by HT. Regarding OH treatments, a significant decrease $(p<0.05)$ was also registered for the $\mathrm{OH}-45{ }^{\circ} \mathrm{C}(1.5 \%)$ and $\mathrm{OH}-55{ }^{\circ} \mathrm{C}$ samples $(3.6 \%)$. However, the treatment $\mathrm{OH}-35{ }^{\circ} \mathrm{C}$ had a decline of only $0.9 \%$, which was not statistically significant $(p>0.05)$ compared to untreated samples. This loss can be correlated with the well-known vitamin $\mathrm{C}$ degradation susceptibility to temperature (Castro et al., 2004; Vikram et al., 2005). Ribeiro et al. (2007) reported substantial losses of ascorbic acid when chestnuts were roasted (46.6-66.0\%), boiled (42.3-55.1\%), or fried (58.4-59.5\%), but these processes use higher heating temperatures and thermal loads $\left(100-200{ }^{\circ} \mathrm{C}\right.$ for $\left.7-40 \mathrm{~min}\right)$. On the other hand, Vikram et al. (2005) and Castro et al. (2004) reported that $\mathrm{OH}$ treatments between 50 and $100{ }^{\circ} \mathrm{C}$ did not affect ascorbic acid levels of orange juice and strawberry products.

The retention of chestnuts' nutrients after $\mathrm{OH}$ processing was, overall, higher when compared to the HT treatment. The 
OH-treated chestnuts suffered minimum damage and retained almost all their nutrients $\left(92.4 \%\right.$ for $\mathrm{OH}-35{ }^{\circ} \mathrm{C}, 90.7 \%$ for $\mathrm{OH}-45^{\circ} \mathrm{C}$, and $90 \%$ for $\left.\mathrm{OH}-55{ }^{\circ} \mathrm{C}\right)$. The nutrients retention results are also supported by the calculated cooking values, which were substantially lower for OH-treated chestnuts $(C=$ 0.9 for $\mathrm{OH}-35^{\circ} \mathrm{C}, 1.8$ for $\mathrm{OH}-45^{\circ} \mathrm{C}$, and 2.9 for $\mathrm{OH}-55^{\circ} \mathrm{C}$ ) than for the HT-treated fruits $(C=3.5)$. Thus, in general, one can conclude that $\mathrm{OH}$ did not substantially change the original nutritional characteristics of the chestnuts. These minimal changes may be due to the rapid, uniform, and internal heating generated by the moderate electric field technology. Other technologies as gamma and electron beam irradiation, when applied at $1 \mathrm{kGy}$, did not cause substantial changes in chestnut composition either (Carocho et al., 2014). However, according to Kwon et al. (2004), irradiation doses below $3 \mathrm{kGy}$ do not have an immediate effect on the elimination of chestnut insects, which may lead to microbiological safety problems during storage.

\section{Shelf-Life Studies}

Fungi growth and weight losses due to dehydration are two of the major concerns in chestnut's post-harvest preservation since they may affect their shelf-life and, consequently, lead to severe economic losses.

\section{Microbial Analysis}

In chestnut samples, bacteria CFU were not detected before or immediately after treatments. Moreover, the samples did not show any bacteria CFU during the shelf-life study in both storage conditions (data not shown). Similar results were found by Blaiotta et al. (2014), who reported the absence of bacteria on Italian chestnut samples processed by water curing for 6 days. Several authors also consider that fungi rather than bacteria are the most significant chestnut post-harvest problem (Botondi et al., 2009; Fernandes et al., 2011a; Prencipe et al., 2018).

The fungal growth trend of untreated and treated chestnuts along the 60 days of storage under room and refrigerated temperatures is shown in Fig. 3. The results show significant differences $(p<0.05)$ in fungi counts in all the treatments compared with untreated samples.

At the beginning of the chestnut shelf-life study (day 0), untreated samples revealed fungi (3.8 Log CFU/g), although visual fungal growth was not observed. The obtained values agree with the $3.7 \mathrm{Log} \mathrm{CFU} / \mathrm{g}$ found by Fernandes et al. $(2020 \mathrm{a}, \mathrm{b})$ in untreated chestnuts. The chestnut microbiota is acquired in the field, especially during the harvesting period since farmers gather the chestnuts from the soil after they fall naturally off the trees. Additionally, chestnuts' microbiota may suffer considerable changes if fruits are not rapid and adequately processed and stored.

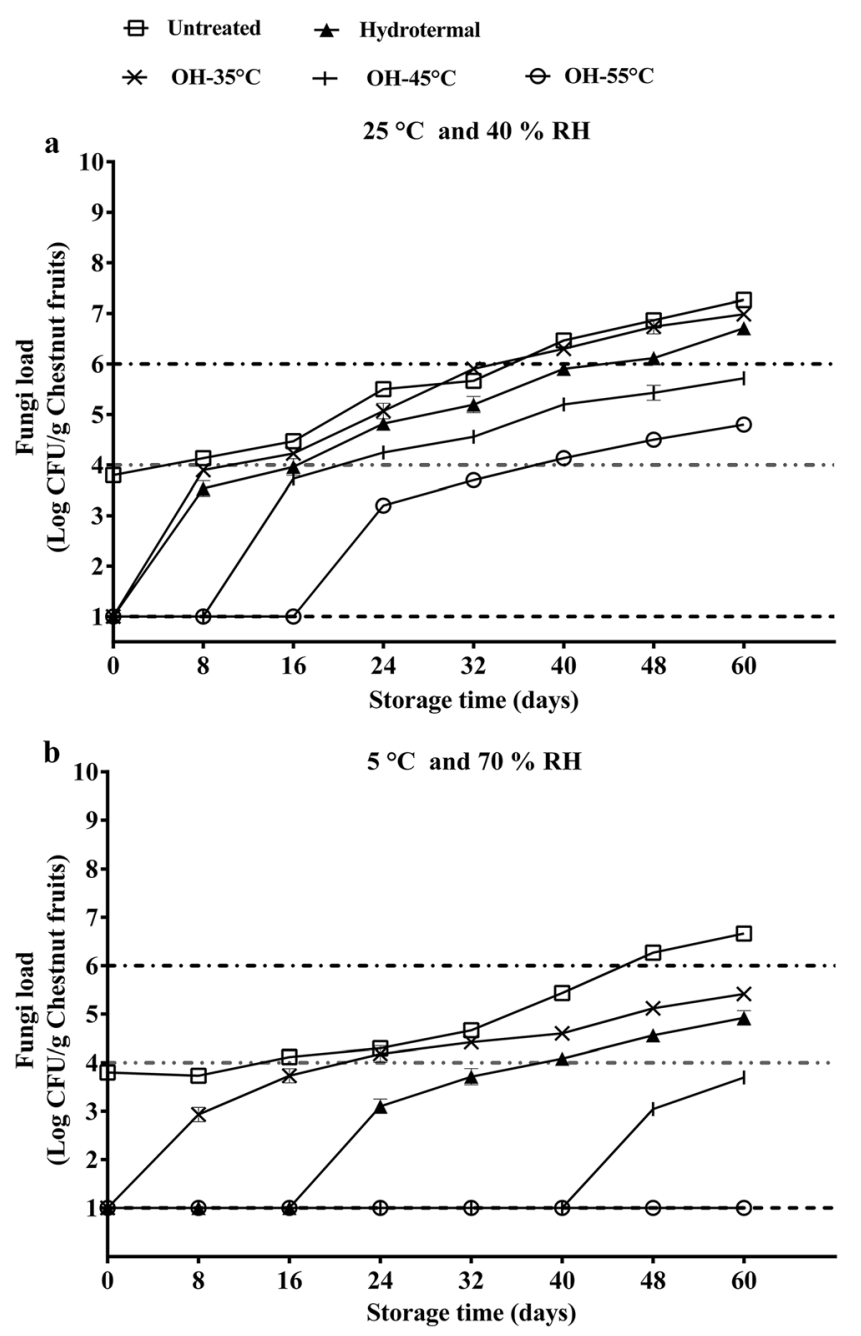

Fig. 3 Chestnuts' fungal load over the 60 days of storage under the different atmospheric conditions tested. Values $=1$ correspond undetectable fungi (- - -). Values $<4$ correspond to the absence of visible molds $(-\cdots-)$. Values between 4 and 6 correspond to some occurrence of visible molds. Values $\geq 6$ correspond to the heavy occurrence of visible molds $(-\cdot-)$. Untreated - not processed, Hydrothermal - conventional treatment, $\mathrm{OH}-$ ohmic heating

In Fig. 3, it can also be observed that $\mathrm{HT}$ and $\mathrm{OH}$ treatments can reduce the initial fungal load of chestnuts, as no fungal counts were detected immediately after processing (day 0). In $\mathrm{OH}$ samples, the CFU decreases cannot just be only explained by the Joule effect because the temperature used in the $\mathrm{OH}-35{ }^{\circ} \mathrm{C}$ treatment is non-lethal for fungi. According to Dix \& Webster (1995), most fungi have optimal growth temperatures between 25 and $30^{\circ} \mathrm{C}$ and can tolerate temperatures from 5 to $35^{\circ} \mathrm{C}$. However, previous studies have shown that moderate electric fields $(<1000 \mathrm{~V} / \mathrm{cm})$ can inactivate some vegetative cells of microorganisms at room temperature (Machado et al., 2010). From a practical point of view, it may not be interesting to treat chestnuts by $\mathrm{OH}-35^{\circ} \mathrm{C}$, but the results are useful to demonstrate that even mild $\mathrm{OH}$ treatments promote fungal inactivation due to the presence of moderate electric fields. 
Although no CFU could be detected on day 0 , fungi have been detected later on during the fruits' storage. This means that some fungal structures (most likely, spores) could withstand the treatments and developed during the storage period. Therefore, the treatments' efficacy can be correlated with the number of storage days during which the chestnuts remained without CFU. Thus, the less effective treatment was OH-35 ${ }^{\circ} \mathrm{C}$ since fungi could be detected in chestnuts right after 8 days of storage, whether at $25^{\circ} \mathrm{C}$ or $5{ }^{\circ} \mathrm{C}(3.9$ and $2.9 \mathrm{Log} \mathrm{CFU} / \mathrm{g}$, respectively). On the other hand, the most effective treatment was $\mathrm{OH}-55{ }^{\circ} \mathrm{C}$, because no CFU were detected in chestnuts preserved at $5{ }^{\circ} \mathrm{C}$ during the 60 days' storage period; and because at $25^{\circ} \mathrm{C}, \mathrm{CFU}(3.2 \mathrm{Log} \mathrm{CFU} / \mathrm{g})$ started to appear only after 24 days. Chestnuts treated by $\mathrm{OH}-45^{\circ} \mathrm{C}$ showed a microbiological evolution in between those registered for $\mathrm{OH}-35$ ${ }^{\circ} \mathrm{C}$ and $\mathrm{OH}-55^{\circ} \mathrm{C}$ treatments. When stored at $5{ }^{\circ} \mathrm{C}, \mathrm{CFU}$ were only detected after 48 days (3.0 Log CFU/g), while when stored at $25{ }^{\circ} \mathrm{C}$, they were detected right after 16 days $(3.7$ $\mathrm{Log} \mathrm{CFU} / \mathrm{g}$ ). In what concerns HT, CFU of fungi were detected right after 8 days ( $3.5 \mathrm{Log} \mathrm{CFU} / \mathrm{g}$ ) when chestnuts storage was done at $25^{\circ} \mathrm{C}$, and only after 24 days $(3.1 \mathrm{Log} \mathrm{CFU} / \mathrm{g})$ when they were stored at $5{ }^{\circ} \mathrm{C}$. In this sense, HT registered a CFU profile similar to $\mathrm{OH}-35{ }^{\circ} \mathrm{C}$ when the chestnuts were stored at room temperature, but at $5{ }^{\circ} \mathrm{C}$, HT performed better than $\mathrm{OH}-35^{\circ} \mathrm{C}$.

In summary, chestnuts treated by $\mathrm{OH}-55^{\circ} \mathrm{C}$ and stored at 5 ${ }^{\circ} \mathrm{C}$ and $70 \% \mathrm{RH}$ maintained no detectable fungi for more 36 days than HT-treated fruits, increasing their shelf-life considerably. Other technologies did not perform so well. For example, Vettraino et al. (2020) observed that chestnuts' fungal population was not fully controlled by gaseous ozone treatments even when the fruits were stored at $2{ }^{\circ} \mathrm{C}$. Also, despite $\gamma$-rays and electron beam irradiation capability to eliminate microbes on chestnuts (Zhu, 2016), the total elimination of fungi is only obtained with doses between 3 and $5 \mathrm{kGy}$ (Antonio et al., 2012), and according to Carocho et al. (2014), undesirable physicochemical changes are observed on chestnuts when irradiation doses $>1 \mathrm{kGy}$ are used.

\section{Weight Loss}

The weight loss of untreated and treated chestnuts along the 60 days of storage under room and refrigeration temperature conditions is shown in Fig. 4. The weight loss showed significant differences $(p<0.05)$ between some treatments when the samples were stored at $25^{\circ} \mathrm{C}$, while no significant differences were observed when the storage was done at $5{ }^{\circ} \mathrm{C}$. Also, a gradual weight decrease was observed during storage regardless of the treatment or storage conditions, which means the fruits have dehydrated. However, the weight loss rate was more pronounced in chestnuts stored at $25^{\circ} \mathrm{C}$ than at $5{ }^{\circ} \mathrm{C}$. This is due to the combined effects of respiration and transpiration processes of chestnuts, and the temperature and $\mathrm{RH}$ of

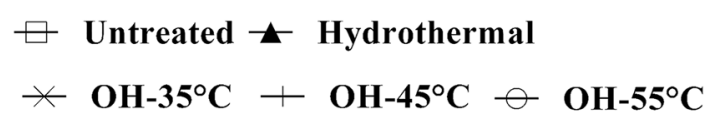

$$
\text { a } \quad 25^{\circ} \mathrm{C} \text { and } 40 \% \text { RH }
$$

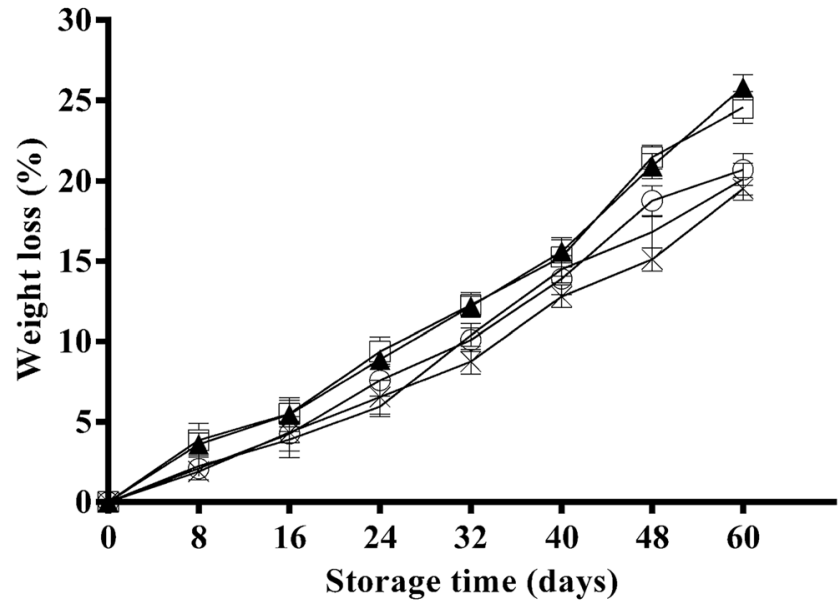

b $\quad 5^{\circ} \mathrm{C}$ and $70 \% \mathrm{RH}$

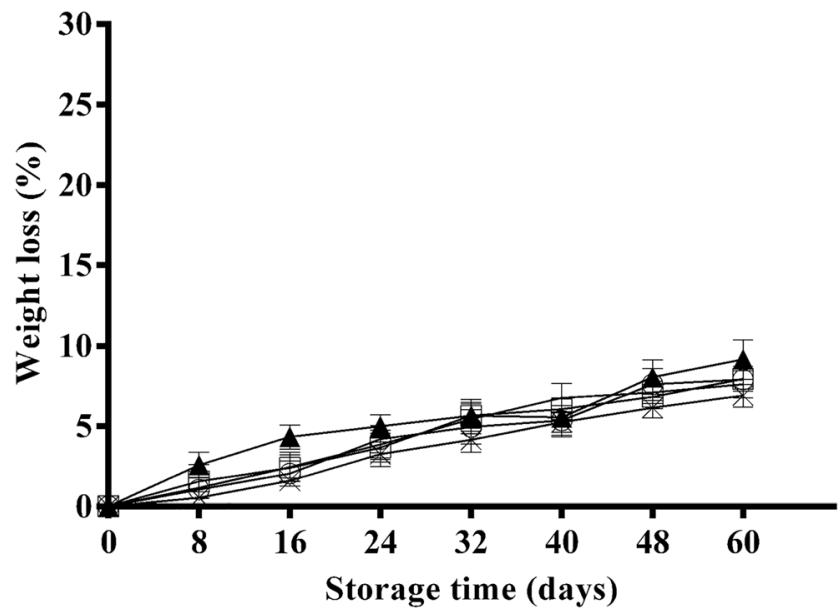

Fig. 4 Weight loss of the chestnuts over the 60 days of storage under different atmospheric conditions. Untreated - not processed, Hydrothermal - conventional treatment, $\mathrm{OH}$ - ohmic heating

surrounding air. The constant balance between those parameters influences the fruits' moisture content and, consequently, their weight. The loss of weight and dehydration of chestnuts over the storage period was also observed by Zhao et al. (2018) when using $15-25{ }^{\circ} \mathrm{C}$ and RH of $20-40 \%$, and by Hou et al. (2014) at $35^{\circ} \mathrm{C}$ and $95 \%$ RH. Therefore, chestnuts require particular storage conditions with minimal equilibrium RH of $85 \%$ (GDV, 1999). However, although high RH can be more efficient in reducing weight loss, it can generate a considerable risk of mold development (GDV, 1999). Still, Vettraino et al. $(2019,2020)$ found weight losses around $2 \%$ per month in Italian chestnuts stored at $2{ }^{\circ} \mathrm{C}$ and $95 \% \mathrm{RH}$ whether treated or not with ozone. 
In this study, untreated chestnut samples lost approximately $12 \%$ of their weight during the first 30 days of storage at 25 ${ }^{\circ} \mathrm{C}$ and $40 \% \mathrm{RH}$, while at the end of 60 days, the weight loss was $24 \%$. It is essential to highlight that weight loss as high as $55 \%$ and $82 \%$ have been previously reported for Chinese chestnuts when using temperatures between 15 and $25{ }^{\circ} \mathrm{C}$ and RH around 20-40\% (Wang et al., 2020; Zhao et al., 2018). On the other hand, when chestnuts were stored at 5 ${ }^{\circ} \mathrm{C}$ and $70 \% \mathrm{RH}$, the weight loss was around $6 \%$ in the first 30 days and $8 \%$ after the full 60 days of storage.

The weight loss of HT samples was higher than that of chestnuts treated by $\mathrm{OH}$. Nonetheless, there were no significant differences in weight among the fruits processed with $\mathrm{OH}(35,45$, and $55^{\circ} \mathrm{C}$ ). The HT chestnuts suffered weight losses around 12 and $26 \%$ after 30 and 60 days of storage at $25^{\circ} \mathrm{C}$, respectively, in a similar trend to that observed for untreated chestnuts. $\mathrm{OH}$ treated chestnuts stored at $25{ }^{\circ} \mathrm{C}$ recorded weight losses around 10 and $21 \%$ after 30 and 60 days, respectively. In refrigerated conditions, the weight losses were around 6-4\% after 30 days and $9-8 \%$ after 60 days for $\mathrm{HT}$ and $\mathrm{OH}$ treatments.

The observed losses of weight indicate that the industry should avoid chestnuts storage at room temperature and, instead, favor their storage on refrigerated conditions with high RH in order to keep the product's characteristics as similar as possible to fresh chestnuts.

\section{Color Measurements}

At the beginning of the shelf-life study (0 days), untreated and treated chestnut kernels showed predominantly light and

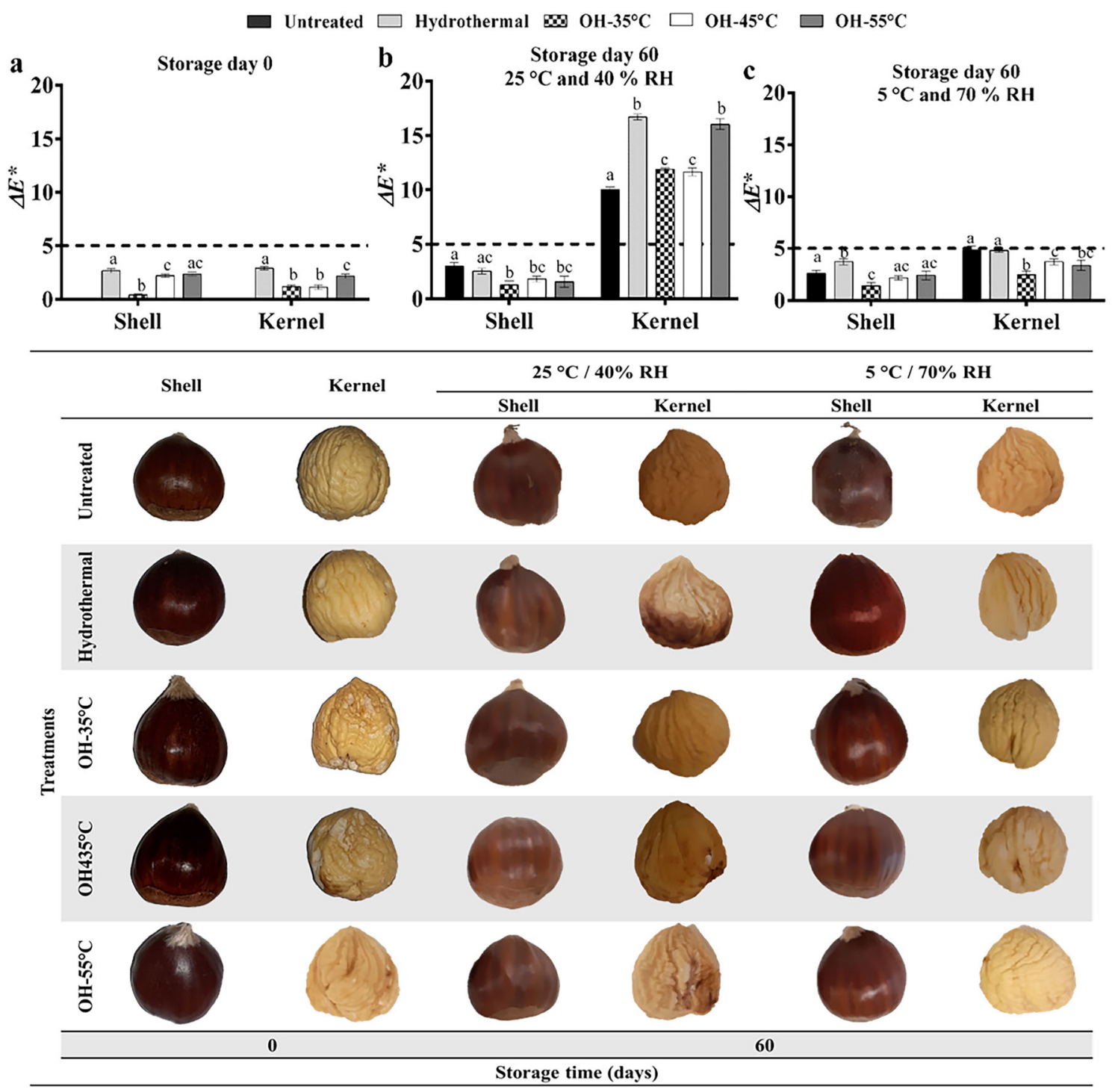

Fig. 5 (a-c) Color difference $\left(\Delta E^{*}\right)$ and images of the chestnuts after 0 and 60 days of storage under the different atmospheric conditions. Value $\Delta E^{*} \geq 5$ indicates substantial color differences that can be perceived by the human eye (Cecchini et al., 2011). Untreated - not processed,
Hydrothermal - conventional treatment, $\mathrm{OH}$ - ohmic heating. Bars with different letters on the same data set indicate a significant difference between the samples $(p<0.05)$ 
bright yellowish color, while the shell showed a bright dark brown color. Due to the difficulty of interpreting the parameters that define color, it was chosen to express the color changes as a color difference $\left(\Delta E^{*}\right)$ (Fig. 5). Pictures of untreated and treated chestnuts taken at 0 and 60 days of storage at 5 and $25{ }^{\circ} \mathrm{C}$ are also shown. The values of $\Delta E^{*}$ registered immediately after the processing of chestnuts (day 0 ) were all below 5 (Fig. 5a), regardless of the treatment process, which means that differences were not perceptible to the human eye, according to Cecchini et al. (2011). This indicates that none of the treatments has significantly affected the visual appearance of chestnuts' kernel and shell.
Fig. 6 Texture characterization of the chestnuts after 0 and 60 days of storage under the different atmospheric conditions. The dotted line in the graphs represents the reference value for the untreated chestnut on day 0 .

(a) The test was performed on the whole chestnut (kernel with shell). (b) The test was performed on the chestnut' kernel. Untreated - not processed, Hydrothermal conventional treatment, $\mathrm{OH}$ ohmic heating, Control - day 0 for each treatment. Bars with different small letters on the same graph indicate a significant difference between the samples $(p<$ 0.05 ). Bars with different capital letters indicate a significant difference between treatments at 0 days $(p<0.05)$ a
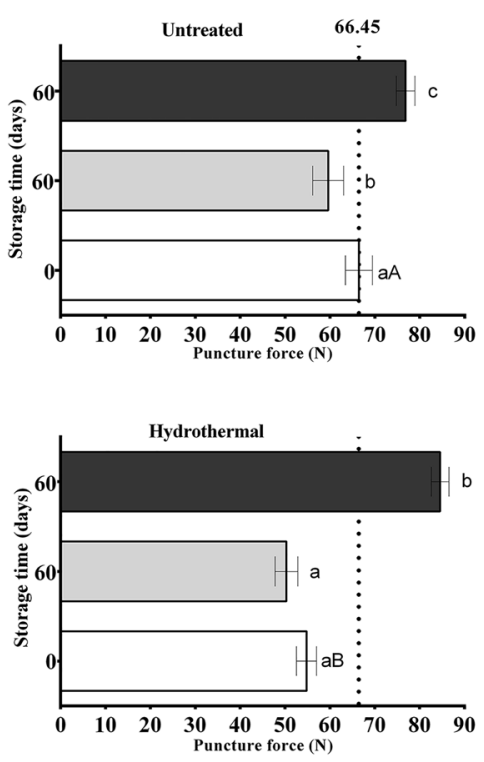

$\mathrm{OH}-35^{\circ} \mathrm{C}$

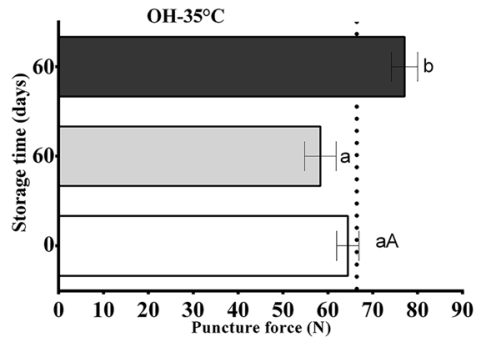

$\mathrm{OH}-45^{\circ} \mathrm{C}$
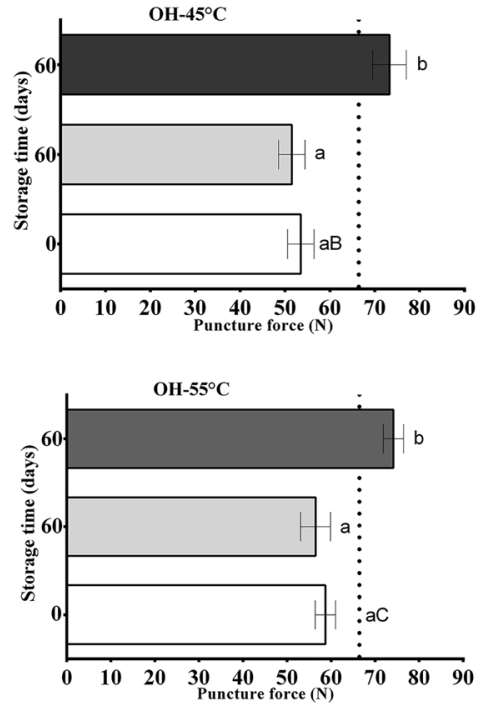

\section{b Compression test}
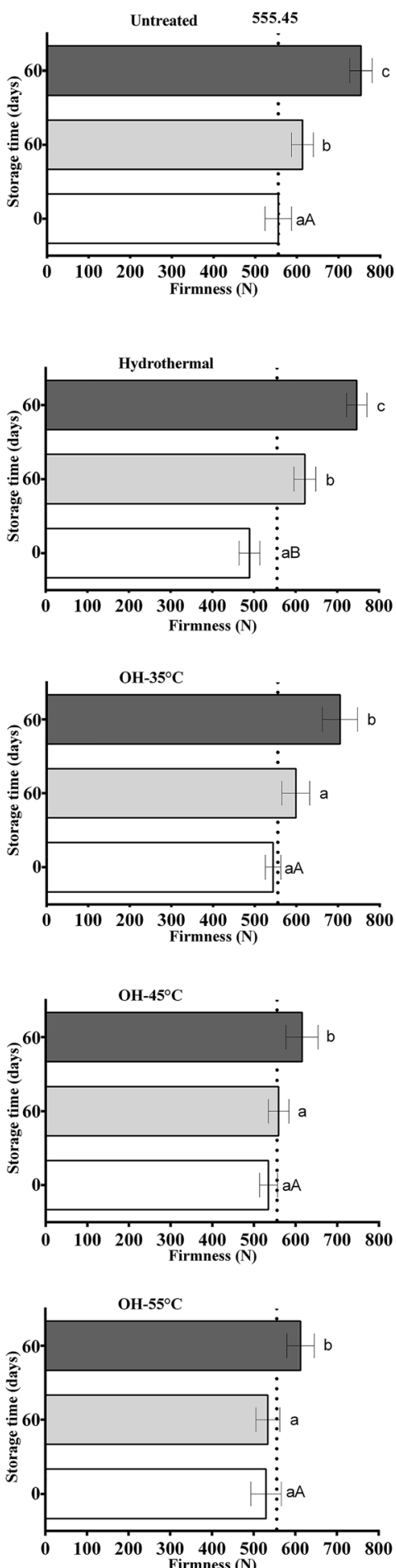
On the other hand, the $\Delta E^{*}$ values obtained at the end of the 60 days of storage showed an increasing trend, regardless of treatments and storage conditions (Fig. $5 \mathrm{~b}$ and c). $\Delta E^{*}$ values $>5$ were registered on the chestnuts' kernels stored at $25^{\circ} \mathrm{C}$ and $40 \%$ RH. Specifically, the kernel became dark yellow without brightness. The results also show that the kernels' color changes were much more perceptible visually than those observed on the chestnuts' shell. Zhao et al. (2018) reported a similar behavior on Chinese chestnuts stored at $15-25^{\circ} \mathrm{C}$ and $20-40 \% \mathrm{RH}$, with a color change from bright to dark yellow. Additionally, if we compare Fig. $5 \mathrm{~b}$ and c, it is clear that storage under refrigerated conditions prevents changes of color on chestnuts' kernels, as the $\Delta E^{*}$ values of chestnuts stored at cold conditions were below 5 , independently of treatment done, while those stored at $25^{\circ} \mathrm{C}$ were all beyond 10 .

\section{Texture Measurements}

Despite the hardness of the shell and kernel of fresh chestnuts, this fruit needs careful handling during harvesting and postharvesting stages to avoid damage and future fruit decay. The hardness of the fruits is an essential quality parameter for consumers.

At the beginning of the shelf-life study (0 days), untreated chestnuts showed a high turgidity, registering high values of puncture force $(66.5 \mathrm{~N})$ and compression $(555.5 \mathrm{~N})$. On the other hand, immediately after the treatments, the puncture force applied to the chestnut samples showed lower values than in untreated samples (Fig. 6a), which implies that chestnuts suffered some kind of softening. The more significant change was recorded for HT samples, while the slightest change was recorded for $\mathrm{OH}-35^{\circ} \mathrm{C}$. Thus, the fruit's softening increased with the temperature and processing time, probably due to increased cooking value.

In what concerns the compression tests applied immediately after the treatments (Fig. 6b), no significant differences $(p>$ 0.05 ) were observed between $\mathrm{OH}$-treated chestnuts and untreated ones, but some softening was registered for HT-treated samples. These changes could also be attributed to the fruits' cooking value in both situations since they may have changed chestnut starch properties. Kan et al. (2016) also reported the softening of chestnuts' kernels treated with hot water. The kernel's hardness decreased as the cooking degree increased; thus, texture parameters could be measured as a function of the moisture and total starch contents.

The values recorded for the puncture and compression tests for all the treatments studied shown significant differences $(p<0.05)$ and an increasing trend when the samples were stored at room temperature conditions. Visually, the chestnut kernels shrank and hardened due to dehydration phenomena, which justifies the higher puncture and compression forces. The results obtained agree with Kan et al. (2016), who reported that chestnuts' hardness increases as the moisture content decreases; and with Zhao et al. (2018), who observed that chestnuts rapidly lost moisture at room temperature, causing the drying and stiffness of kernels. On the other hand, when the chestnuts were stored in cold conditions, they could maintain their turgescence and texture characteristics more similar to untreated fruits. This behavior could be attributed to the delay of the fruit maturation process due to the low temperature and the higher $\mathrm{RH}$ at storage.

Table 2 Result of chestnuts' visual inspection after 0,30, and 60 days of storage under the different atmospheric conditions tested

\begin{tabular}{|c|c|c|c|c|c|c|c|c|c|c|c|c|c|c|c|c|}
\hline \multirow[t]{4}{*}{ Storage conditions } & \multirow[t]{4}{*}{ Treatments } & \multicolumn{15}{|c|}{ Parameters/storage time (days) } \\
\hline & & \multicolumn{6}{|c|}{ Visual molds } & \multicolumn{3}{|c|}{ Dried } & \multicolumn{3}{|c|}{ Sprouting } & \multicolumn{3}{|c|}{ Insect larvae } \\
\hline & & \multicolumn{3}{|c|}{ Shell } & \multicolumn{3}{|c|}{ Kernel } & & & & & & & & & \\
\hline & & 0 & 30 & 60 & 0 & 30 & 60 & 0 & 30 & 60 & 0 & 30 & 60 & 0 & 30 & 60 \\
\hline \multirow[t]{5}{*}{$25^{\circ} \mathrm{C}$ and $40 \% \mathrm{RH}$} & Untreated & - & \pm & \pm & - & \pm & + & - & \pm & + & - & \pm & + & - & + & - \\
\hline & Hydrothermal & - & \pm & \pm & - & \pm & + & - & \pm & + & - & - & - & - & + & - \\
\hline & $\mathrm{OH}-35^{\circ} \mathrm{C}$ & - & \pm & \pm & - & \pm & + & - & \pm & + & - & - & - & - & + & - \\
\hline & $\mathrm{OH}-45^{\circ} \mathrm{C}$ & - & - & \pm & - & \pm & \pm & - & \pm & + & - & - & - & - & - & - \\
\hline & $\mathrm{OH}-55^{\circ} \mathrm{C}$ & - & - & \pm & - & - & \pm & - & \pm & + & - & - & - & - & - & - \\
\hline \multirow[t]{5}{*}{$5^{\circ} \mathrm{C}$ and $70 \% \mathrm{RH}$} & Untreated & - & - & \pm & - & \pm & + & - & - & \pm & - & - & \pm & - & \pm & - \\
\hline & Hydrothermal & - & - & \pm & - & - & \pm & - & - & \pm & - & - & - & - & \pm & - \\
\hline & $\mathrm{OH}-35^{\circ} \mathrm{C}$ & - & - & \pm & - & \pm & \pm & - & - & \pm & - & - & - & - & \pm & - \\
\hline & $\mathrm{OH}-45^{\circ} \mathrm{C}$ & - & - & \pm & - & - & \pm & - & - & \pm & - & - & - & - & - & - \\
\hline & $\mathrm{OH}-55^{\circ} \mathrm{C}$ & - & - & - & - & - & - & - & - & \pm & - & - & - & - & - & - \\
\hline
\end{tabular}

(-) absence; $( \pm$ ) some occurrence; $(+)$ heavy occurrence. Untreated - not processed, Hydrothermal - conventional treatment, $\mathrm{OH}-\mathrm{ohmic}$ heating 


\section{Visual Quality Assessment}

The visual quality assessment of chestnut samples at 0,30 , and 60 days of storage under room and refrigeration temperature conditions are shown in Table 2. In general, the visual defects of chestnut quality increased over the storage period. Before and immediately after the treatments $(0$ days), the chestnuts were devoid of visible molds, both on shells and kernels, and any insect larvae, sprouting, and dehydration. Similar results were obtained by Hou et al. (2015), who did not found insect larvae immediately after applying radiofrequency treatments to Chinese chestnuts (46-50 ${ }^{\circ} \mathrm{C}$ for $2-8 \mathrm{~min}$ ).

However, control and chestnuts treated with $\mathrm{HT}$ and $\mathrm{OH}-$ $35^{\circ} \mathrm{C}$ showed insect larvae at the end of 30 days regardless of the storage conditions. Migliorini et al. (2010) also detected insect larvae in untreated chestnuts after 30 days of storage. HT- and $\mathrm{OH}-35^{\circ} \mathrm{C}$-treated samples also evidenced a substantial occurrence of visible molds in the chestnut kernel after 60 days of storage. Vettraino et al. (2019) reported a similar development of fungi on chestnuts during their storage for 150 days at $2{ }^{\circ} \mathrm{C}$ after being treated with ozone. Concerning insect larvae and visible molds, untreated chestnuts, $\mathrm{HT}$, and $\mathrm{OH}-35$ ${ }^{\circ} \mathrm{C}$-treated chestnuts stored at $25^{\circ} \mathrm{C}$ were the most affected. In the control treatment, it was also observed some occurrence of sprouting during the first 30 days of storage.

The visual evaluation confirmed that the most effective treatment was $\mathrm{OH}-55{ }^{\circ} \mathrm{C}$ when combined with storage at 5 ${ }^{\circ} \mathrm{C}$ and $70 \% \mathrm{RH}$, since no visible molds, sprouting, and insect larvae were observed during the 60 days of storage. Other conservation technologies as $\gamma$-rays irradiation can also eliminate insects on chestnuts. According to Kwon et al. (2004), chestnuts' irradiation at $0.5 \mathrm{kGy}$ showed $100 \%$ of insect mortality after 3 to 4 weeks of storage. However, immediate insect mortality of $100 \%$ is only achievable with 3 or more $\mathrm{kGy}$, and stored chestnuts suffer a significant change of color when the irradiation doses were superior to $1 \mathrm{kGy}$.

\section{Conclusion}

This study concludes that the microbiological quality and the shelf-life of chestnuts are strongly dependent on the postharvest technology used in their treatment and clearly shows the importance of the processing parameters and storage conditions such as temperature and $\mathrm{RH}$. $\mathrm{OH}$ is an alternative processing technology where heat is generated directly within the chestnut samples (rapid volumetric heating), resulting in the elimination of the problems associated with heat transfer. The microbiological results of $\mathrm{OH}$ treatments showed that the application of moderate electric fields for a few minutes at mild temperatures can reduce the fungal burden in chestnuts. The $\mathrm{OH}$ treatment performed at $55{ }^{\circ} \mathrm{C}$ in combination with storage at $5{ }^{\circ} \mathrm{C}$ and $70 \% \mathrm{RH}$ proved to be an effective alternative to the conventional HT, currently used by the chestnut industry. With the $\mathrm{OH}-55{ }^{\circ} \mathrm{C}$ treatment, no fungal decay was observed during the 60-day storage period, and the shelf-life of chestnuts was extended by 36 days when compared to HT. This method also presents clear advantages at the industrial level compared to HT since the chestnuts' treatment time can be reduced to $3.3 \mathrm{~min}$, allowing considerable energy savings. Additionally, the physicochemical characteristics of chestnuts treated by $\mathrm{OH}-55^{\circ} \mathrm{C}$ and stored for 60 days showed that fresh fruits' quality can be preserved. Quality parameters such as retention of nutrients, texture, and fruits' color immediately after the treatment were not significantly different from untreated chestnuts. Moreover, fungi, insect larvae, and sprouting were absent. These results encourage further studies to assess the industrial application of $\mathrm{OH}$ in the post-harvest treatment of chestnuts.

Author Contribution Enrique Pino-Hernández: investigation, formal analysis, visualization, writing - original draft.

Ricardo N. Pereira: conceptualization, methodology, writing - review and editing.

Lina F. Ballesteros: investigation, writing - review and editing.

António A. Vicente: conceptualization, resources, writing - review and editing.

Luís Abrunhosa: conceptualization, methodology, writing - review and editing, supervision.

José A. Teixeira: funding acquisition, writing - review and editing, supervision.

Funding This study was supported by the Portuguese Foundation for Science and Technology (FCT) under the scope of the strategic funding of UID/BIO/04469/2020 unit and BioTecNorte operation (NORTE-010145-FEDER-000004) funded by the European Regional Development Fund under the scope of Norte2020 - Programa Operacional Regional do Norte. Enrique Pino-Hernández is a recipient of a fellowship supported by an advanced doctoral training program (call NORTE-69-2015-15), funded by the European Social Fund under the scope of Norte2020 Programa Operacional Regional do Norte (NORTE-08-5369-FSE000036). Ricardo N. Pereira and Luís Abrunhosa acknowledge FCT for their Assistant Research contract obtained under CEEC Individual 2017: reference CEECIND/02903/2017 and CEECIND/00728/2017, respectively.

\section{Declarations}

Conflict of Interest The authors declare no competing interests.

\section{References}

Antonio, A. L., Carocho, M., Bento, A., Quintana, B., Luisa Botelho, M., \& Ferreira, I. C. F. R. (2012). Effects of gamma radiation on the biological, physico-chemical, nutritional and antioxidant parameters of chestnuts - a review. Food and Chemical Toxicology, 50(9), 3234-3242. https://doi.org/10.1016/j.fct.2012.06.024

Barreira, J. C. M., Antonio, A. L., Günaydi, T., Alkan, H., Bento, A., Luisa Botelho, M., \& Ferreira, I. C. F. R. (2012). Chemometric 
characterization of gamma irradiated chestnuts from Turkey. Radiation Physics and Chemistry, 81(9), 1520-1524. https://doi. org/10.1016/j.radphyschem.2012.01.005

Blaiotta, G., Di Capua, M., Romano, A., Coppola, R., \& Aponte, M. (2014). Optimization of water curing for the preservation of chestnuts (Castanea sativa Mill.) and evaluation of microbial dynamics during process. Food Microbiology, 42, 47-55. https://doi.org/10. 1016/j.fm.2014.02.009

Bogna, A., \& Piekarski, J. (2000). Guidelines for recipe information and calculation of nutrient composition of preared foods (dishes). Journal of Food Composition and Analysis, 13(4), 391-410. https://doi.org/10.1006/jfca.2000.0922

Botondi, R., Vailati, M., Bellincontro, A., Massantini, R., Forniti, R., \& Mencarelli, F. (2009). Technological parameters of water curing affect post-harvest physiology and storage of marrons (Castanea sativa Mill., Marrone fiorentino). Postharvest Biology and Technology, 51(1), 97-103. https://doi.org/10.1016/j.postharvbio. 2008.06.010

Bounous, G., Barrel, A., Beccaro, G., Lovisolo, C., \& Pereira, J. G. (2002). Inventory of chestnut research, germplasm and references. Rome: FAO Regional Office for Europe http://www.fao.org/3/ ad235e/ad235e00.htm\#Contents

Carocho, M., Antonio, A. L., Barreira, J. C. M., Rafalski, A., Bento, A., \& Ferreira, I. C. F. R. (2014). Validation of gamma and electron beam irradiation as alternative conservation technology for european chestnuts. Food and Bioprocess Technology, 7(7), 1917-1927. https://doi.org/10.1007/s11947-013-1186-5

Carocho, M., Barreira, J. C. M., Antonio, A. L., Bento, A., Kaluska, I., \& Ferreira, I. C. F. R. (2012). Effects of electron-beam radiation on nutritional parameters of Portuguese chestnuts (Castanea sativa Mill.). Journal of Agricultural and Food Chemistry, 60(31), 7754 7760. https://doi.org/10.1021/jf302230t

Castro, I., Teixeira, J. A., Salengke, S., Sastry, S. K., \& Vicente, A. A. (2004). Ohmic heating of strawberry products: electrical conductivity measurements and ascorbic acid degradation kinetics. Innovative Food Science and Emerging Technologies, 5(1), 27-36. https://doi. org/10.1016/j.ifset.2003.11.001

Cecchini, M., Contini, M., Massantini, R., Monarca, D., \& Moscetti, R. (2011). Effects of controlled atmospheres and low temperature on storability of chestnuts manually and mechanically harvested. Postharvest Biology and Technology, 61(2-3), 131-136. https:// doi.org/10.1016/j.postharvbio.2011.03.001

Correia, P., Cruz-Lopes, L., \& Beirão-da-Costa, L. (2012). Morphology and structure of chestnut starch isolated by alkali and enzymatic methods. Food Hydrocolloids, 28(2), 313-319. https://doi.org/10. 1016/j.foodhyd.2011.12.013

Correia, P., Leitão, A., \& Beirão-da-Costa, M. L. (2009). The effect of drying temperatures on morphological and chemical properties of dried chestnuts flours. Journal of Food Engineering, 90(3), 325332. https://doi.org/10.1016/j.jfoodeng.2008.06.040

Cruz, B. R., Abraão, A. S., Lemos, A. M., \& Nunes, F. M. (2013). Chemical composition and functional properties of native chestnut starch (Castanea sativa Mill). Carbohydrate Polymers, 94(1), 594602. https://doi.org/10.1016/j.carbpol.2012.12.060

Dix, N. J., \& Webster, J. (1995). Fungi of extreme environments. In Fungal ecology (pp. 322-340). Dordrecht, Netherlands: Springer

FAOSTAT. (2020). Crops. Food and Agriculture Organization of the United Nations. http://faostat.fao.org/site/339/default.aspx

Fernandes, Â., Antonio, A. L., Barros, L., Barreira, J. C. M., Bento, A., Botelho, M. L., \& Ferreira, I. C. F. R. (2011a). Low dose yirradiation as a suitable solution for chestnut (Castanea sativa Miller) conservation: effects on sugars, fatty acids, and tocopherols. Journal of Agricultural and Food Chemistry, 59(18), 10028-10033. https://doi.org/10.1021/jf201706y

Fernandes, Â., Barreira, J. C. M., Antonio, A. L., Bento, A., Luisa Botelho, M., \& Ferreira, I. C. F. R. (2011b). Assessing the effects of gamma irradiation and storage time in energetic value and in major individual nutrients of chestnuts. Food and Chemical Toxicology, 49(9), 2429-2432. https://doi.org/10.1016/j.fct.2011. 06.062

Fernandes, L., Pereira, E. L., do Céu Fidalgo, M., Gomes, A., \& Ramalhosa, E. (2020a). Physicochemical properties and microbial control of chestnuts (Castanea sativa) coated with whey protein isolate, chitosan and alginate during storage. Scientia Horticulturae, 263, 109105. https://doi.org/10.1016/j.scienta.2019. 109105

Fernandes, L., Pereira, E. L., Fidalgo, M. D. C., Gomes, A., \& Ramalhosa, E. (2020b). Effect of modified atmosphere, vacuum and polyethylene packaging on physicochemical and microbial quality of chestnuts (Castanea sativa) during storage. International Journal of Fruit Science, 20(sup2), S785-S801. https://doi.org/10.1080/15538362.2020.1768619

GDV. (1999). Chestnuts - transport informations service. Gesamtverband der Deutschen Versicherungswirtschaft. http:// www.tis-gdv.de. Accessed 13 July 2020

Gonçalves, B., Borges, O., Costa, H. S., Bennett, R., Santos, M., \& Silva, A. P. (2010). Metabolite composition of chestnut (Castanea sativa Mill.) upon cooking: proximate analysis, fibre, organic acids and phenolics. Food Chemistry, 122(1), 154-160. https://doi.org/10. 1016/j.foodchem.2010.02.032

Hou, L., Hou, J., Li, Z., Johnson, J. A., \& Wang, S. (2015). Validation of radio frequency treatments as alternative non-chemical methods for disinfesting chestnuts. Journal of Stored Products Research, 63, 7579. https://doi.org/10.1016/j.jspr.2015.07.004

Hou, L., Kou, X., Li, R., \& Wang, S. (2018). Thermal inactivation of fungi in chestnuts by hot air assisted radio frequency treatments. Food Control, 93, 297-304. https://doi.org/10.1016/j.foodcont. 2018.06.016

Hou, L., Ling, B., \& Wang, S. (2014). Development of thermal treatment protocol for disinfesting chestnuts using radio frequency energy. Postharvest Biology and Technology, 98, 65-71. https://doi.org/ 10.1016/j.postharvbio.2014.07.007

Jaeger, H., Roth, A., Toepfl, S., Holzhauser, T., Engel, K. H., Knorr, D., Vogel, R. F., Bandick, N., Kulling, S., Heinz, V., \& Steinberg, P. (2016). Opinion on the use of ohmic heating for the treatment of foods. Trends in Food Science and Technology, 55, 84-97. https:// doi.org/10.1016/j.tifs.2016.07.007

Kan, L., Li, Q., Xie, S., Hu, J., Wu, Y., \& Ouyang, J. (2016). Effect of thermal processing on the physicochemical properties of chestnut starch and textural profile of chestnut kernel. Carbohydrate Polymers, 151, 614-623. https://doi.org/10.1016/j.carbpol.2016. 06.008

Kaur, N., \& Singh, A. K. (2016). Ohmic heating: concept and applications - a review. Critical Reviews in Food Science and Nutrition, 56(14), 2338-2351. https://doi.org/10.1080/10408398. 2013.835303

Kwon, J. H., Kwon, Y. J., Byun, M. W., \& Kim, K. S. (2004). Competitiveness of gamma irradiation with fumigation for chestnuts associated with quarantine and quality security. Radiation Physics and Chemistry, 71(1-2), 41-44. https://doi.org/10.1016/j. radphyschem.2004.04.013

Leyva, A., Quintana, A., Sánchez, M., Rodríguez, E. N., Cremata, J., \& Sánchez, J. C. (2008). Rapid and sensitive anthrone-sulfuric acid assay in microplate format to quantify carbohydrate in biopharmaceutical products: Method development and validation. Biologicals, 36(2), 134-141. https://doi.org/10.1016/j.biologicals.2007.09.001

Li, Q., Shi, X., Zhao, Q., Cui, Y., Ouyang, J. \& Xu, F. (2016). Effect of cooking methods on nutritional quality and volatile compounds of Chinese chestnut (Castanea mollissima Blume). Food Chemistry, 201, 80-86. https://doi.org/10.1016/j.foodchem.2016.01.068

Ling, B., Tang, J., Kong, F., Mitcham, E. J., \& Wang, S. (2015). Kinetics of food quality changes during thermal processing: a review. Food 
and Bioprocess Technology, 8(2), 343-358. https://doi.org/10.1007/ s11947-014-1398-3

Machado, L. F., Pereira, R. N., Martins, R. C., Teixeira, J. A., \& Vicente, A. A. (2010). Moderate electric fields can inactivate Escherichia coli at room temperature. Journal of Food Engineering, 96(4), 520-527. https://doi.org/10.1016/j.jfoodeng.2009.08.035

Migliorini, M., Funghini, L., Marinelli, C., Turchetti, T., Canuti, S., \& Zanoni, B. (2010). Study of water curing for the preservation of marrons (Castanea sativa Mill., Marrone fiorentino cv). Postharvest Biology and Technology, 56(1), 95-100. https://doi. org/10.1016/j.postharvbio.2009.12.001

Neri, L., Dimitri, G., \& Sacchetti, G. (2010). Chemical composition and antioxidant activity of cured chestnuts from three sweet chestnut (Castanea sativa Mill.) ecotypes from Italy. Journal of Food Composition and Analysis, 23(1), 23-29. https://doi.org/10.1016/j. jfca.2009.03.002

Panagou, E. Z., Vekiari, S. A., \& Mallidis, C. (2006). The effect of modified atmosphere packaging of chestnuts in suppressing fungal growth and related physicochemical changes during storage in retail packages at 0 and $8{ }^{\circ} \mathrm{C}$. Advances in Horticultural Science, 20(1), 82-89. https://doi.org/10.1400/14451

Peano, C., Baudino, C., Giuggioli, N. R., \& Girgenti, V. (2014). The use of a modified atmosphere for the storage of chestnut fruits. Italian Journal of Food Science, 26(1), 74-80

Pereira, R. N., \& Vicente, A. A. (2010). Environmental impact of novel thermal and non-thermal technologies in food processing. Food Research International, 43(7), 1936-1943. https://doi.org/10.1016/ j.foodres.2009.09.013

Pereira-Lorenzo, S., Ramos-Cabrer, A. M., Díaz-Hernández, M. B., Ciordia-Ara, M., \& Ríos-Mesa, D. (2006). Chemical composition of chestnut cultivars from Spain. Scientia Horticulturae, 107(3), 306-314. https://doi.org/10.1016/j.scienta.2005.08.008

Prencipe, S., Siciliano, I., Contessa, C., Botta, R., Garibaldi, A., Gullino, M. L., \& Spadaro, D. (2018). Characterization of Aspergillus section Flavi isolated from fresh chestnuts and along the chestnut flour process. Food Microbiology, 69(165), 159-169. https://doi.org/10. 1016/j.fm.2017.08.004

Ribeiro, B., Rangel, J., Valentão, P., Andrade, P. B., Pereira, J. A., Bölke, H., \& Seabra, R. M. (2007). Organic acids in two Portuguese chestnut (Castanea sativa Miller) varieties. Food Chemistry, 100(2), 504-508. https://doi.org/10.1016/j.foodchem.2005.09.073

Silva, A. P., Santos-Ribeiro, R., Borges, O., Magalhães, B., Silva, M. E., \& Gonçalves, B. (2011). Effects of roasting and boiling on the physical and mechanical properties of 11 Portuguese chestnut cultivars (Castanea sativa Mill.). CyTA - Journal of Food, 9(3), 214 219. https://doi.org/10.1080/19476337.2010.518249

Tulsiyan, P., Sarang, S., \& Sastry, S. K. (2008). Electrical conductivity of multicomponent systems during ohmic heating. International
Journal of Food Properties, 11(1), 233-241. https://doi.org/10. 1080/10942910701302580

UNEP. (2014). Report of the methyl bromide technical options committee. MBTOC Assessment Report. Available at: https:// ozone.unep.org/sites/default/files/2019-05/MBTOC-AssessmentReport-2014.pdf

Vettraino, A. M., Bianchini, L., Caradonna, V., Forniti, R., Goffi, V., Zambelli, M., Testa, A., Vinciguerra, V., \& Botondi, R. (2019). Ozone gas as a storage treatment to control Gnomoniopsis castanea, preserving chestnut quality. Journal of the Science of Food and Agriculture, 99(13), 6060-6065. https://doi.org/10.1002/jsfa.9883

Vettraino, A. M., Vinciguerra, V., Pacini, G., Forniti, R., Goffi, V., \& Botondi, R. (2020). Gaseous ozone as a suitable solution for postharvest chestnut storage: evaluation of quality parameter trends. Food and Bioprocess Technology, 13(1), 187-193. https://doi.org/ 10.1007/s11947-019-02378-9

Vikram, V. B., Ramesh, M. N., \& Prapulla, S. G. (2005). Thermal degradation kinetics of nutrients in orange juice heated by electromagnetic and conventional methods. Journal of Food Engineering, 69(1), 31-40. https://doi.org/10.1016/j.jfoodeng.2004.07.013

Wang, Y., Zhao, J., Wu, Y., Wang, M., \& Ouyang, J. (2020). Processing of air-dried chestnut and physicochemical properties of its starch with low digestibility. Food Hydrocolloids, 108, 106051. https:// doi.org/10.1016/j.foodhyd.2020.106051

Wani, I. A., Hamid, H., Hamdani, A. M., Gani, A., \& Ashwar, B. A. (2017). Physico-chemical, rheological and antioxidant properties of sweet chestnut (Castanea sativa Mill.) as affected by pan and microwave roasting. Journal of Advanced Research, 8(4), 399-405. https://doi.org/10.1016/j.jare.2017.05.005

Zhang, L., Wang, Z., Shi, G., Yang, H., Wang, X., Zhao, H., \& Zhao, S. (2018). Effects of drying methods on the nutritional aspects, flavor, and processing properties of Chinese chestnuts. Journal of Food Science and Technology, 55(9), 3391-3398. https://doi.org/10. 1007/s13197-018-3227-6

Zhao, J., Zhang, Y., Wu, Y., Liu, L., \& Ouyang, J. (2018). Physicochemical properties and in vitro digestibility of starch from naturally air-dried chestnut. International Journal of Biological Macromolecules, 117, 1074-1080. https://doi.org/10.1016/j. ijbiomac.2018.06.034

Zhu, F. (2016). Effect of processing on quality attributes of chestnut. Food and Bioprocess Technology, 9(9), 1429-1443. https://doi. org/10.1007/s11947-016-1749-3

Zhu, F. (2017). Properties and Food Uses of Chestnut Flour and Starch. Food and Bioprocess Technology, 10(7), 1173-1191. https://doi. org/10.1007/s1 1947-017-1909-0

Publisher's Note Springer Nature remains neutral with regard to jurisdictional claims in published maps and institutional affiliations. 